\title{
A ordem regional no Oriente Médio 15 anos após os atentados de 11 de Setembro
}

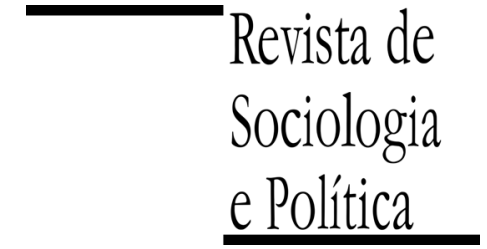

DOI 10.1590/1678-987315235305

\section{Danny Zahreddine e Rodrigo Corrêa Teixeira}

\begin{abstract}
Resumo
O artigo aborda a ordem regional do Oriente Médio 15 anos após os atentados de 11 de setembro de 2001, analisando a relevância das potências regionais para o equilíbrio de poder naquela região. A pergunta a ser respondida é se os atentados de 11 de setembro alteraram de maneira significativa a ordem regional. O objetivo da pesquisa é avaliar o papel das potências regionais para as relações de poder no Oriente Médio e suas transformações após os atentados. Para tanto, serão apresentados os conceitos de poder, ordem e potência regional, bem como uma breve descrição das transformações ocorridas nas relações internacionais do Oriente Médio desde as independências locais até o pós-11 de Setembro. Para categorizar os Estados como potência média, emergente ou regional será utilizado a perspectiva teórica tratada por Nolte (2010), Jordaan (2010) e Huelsz (2009). Para avaliar a distribuição de poder entre os principais atores estatais, bem como sua hierarquia de poder, utiliza-se os conceitos de poder real, potencial e ideacional. São aplicadas técnicas como a Análise de Componentes Principais (ACP), para analisar os períodos de 1980, 1990, 2001 (ano dos atentados) e 2011 (dados mais recentes das fontes consultadas). Os resultados demonstram que as principais forças regionais que historicamente atuaram na região continuam presentes, e que a ordem regional vigente é semelhante à do início da década de 1990, sendo que as principais transformações se deram no campo ideacional em função do aumento da ação de forças transnacionais.
\end{abstract}

PALAVRAS-CHAVE: Oriente Médio; ordem regional; poder; potências regionais; 11 de setembro de 2001.

Recebido em 12 de Agosto de 2014. Aprovado em 12 de Outubro de 2014.

\section{Introduçãa ${ }^{1}$}

\footnotetext{
${ }^{1}$ Agradecemos os pareceristas anônimos da Revista de Sociologia e Política por seus comentários.
}

O problema a ser analisado nesse artigo diz respeito à importância que os atentados de 11 de setembro de 2001 tiveram para o ordenamento regional do Oriente Médio. Desde os atentados contra as Torres Gêmeas, em Nova York, muitos teóricos do campo das Relações Internacionais têm defendido posições contrárias acerca dos seus desdobramentos políticos. Seus impactos na ordem regional ou mundial é o centro do debate, e o objetivo principal é avaliar se existiu mudança significativa no ordenamento regional e se as potências regionais envolvidas nas disputas pela liderança da região são as mesmas desde os atentados de 11 de setembro de 2001.

Em um primeiro momento são apresentadas as lentes teóricas que auxiliaram a compreensão do problema de pesquisa. Para tanto, os conceitos de poder, política internacional e ordem serão tratados para o melhor entendimento do objeto em análise. Além disso, a utilização das definições de potência média tradicional, emergente e regional serão destacadas nessa seção, com o objetivo de demonstrar o papel ativo e permanente desse tipo de ator para as disputas regionais.

A segunda parte do artigo será dedicada à exposição de uma breve história das relações internacionais do Oriente Médio, destacando três momentos principais: $(i)$ das independências locais à Guerra Fria; (ii) do fim da Guerra Fria aos atentados de 11 de setembro de 2001 e (iii) o período posterior aos atentados terroristas de 11 de setembro. Nesse contexto, será dada mais ênfase às des- 
crições que geraram maior impacto para a ordem regional e para as relações dessa região com o restante do Sistema Internacional.

A última seção será responsável pela apresentação dos resultados. A aplicação de estatística descritiva e multivariada auxiliará na compreensão dos fenômenos tratados neste artigo. Avaliar os períodos históricos, confrontando-os com as evidências empíricas permitirá responder de maneira mais adequada à pergunta de partida. A hipótese a ser testada é que os atentados de 11 de setembro de 2001 não geraram mudança significativa nas principais forças estatais regionais do Oriente Médio, sendo que as principais transformações ocorreram em um círculo de poder intermediário, mais suscetível às intervenções externas, e na esfera ideacional, com a ascensão de atores transnacionais.

Os atentados de 11 de setembro de 2001 revelaram mais uma vez a importância do papel do Oriente Médio para a ordem mundial, e evidencia a necessidade de olharmos com mais atenção os fenômenos que envolvem os povos que compõem essa região. Os impactos das ações da Al Qaeda naquele fatídico dia foram sentidos em toda a sociedade internacional, mas seus desdobramentos mais profundos se deram no epicentro da crise, isto é, no Oriente Médio. A invasão do Afeganistão em 7 de outubro de 2001, a invasão do Iraque em 20 de março de 2003 e as políticas de aproximação estadunidense com o Paquistão e com os países do Golfo surtiram efeito importante para aquela área, gerando transformações que devem ser analisadas com atenção.

Desde o início do processo de independência dos Estados Nacionais no Oriente Médio, é possível destacar a importância de alguns atores que desempenharam papel relevante para a condução da política regional. Arábia Saudita, Irã, Turquia e Egito em um primeiro plano, e Israel, Iraque e Síria, em uma segunda esfera de poder. Tais países participaram ativamente da balança de poder do Oriente Médio, e durante décadas, suas ações definiram os desígnios da região.

\section{Da perspectiva teórica}

\section{II.1. Poder, política e ordem internacional}

A discussão acerca do papel do poder nas relações internacionais continua tendo centralidade nos debates entre teóricos e pesquisadores da área. Tanto para o realismo clássico, neoclássico e neorrealismo, como para o institucionalismo, marxismo, construtivismo e outras perspectivas teóricas das Relações Internacionais, essa categoria de análise continua sendo fundamental para a compreensão dos fenômenos internacionais.

Para Carr (2001, p. 135) "embora não se possa definir a política exclusivamente em termos de poder, é seguro dizer-se que o poder é sempre um elemento essencial da política". A capacidade de mudar o comportamento de outro ator é uma das definições genéricas de poder. Seja pela utilização de poder militar, econômico, seja de poder ideacional, as formas que podem ser utilizadas para constranger atores internacionais a mudarem seus comportamentos na arena internacional variam razoavelmente de autores e perspectivas teóricas.

Ainda para Carr (idem), o poder se materializa a partir do poder militar, do poder econômico e da propaganda. Já para os institucionalistas neoliberais, o poder econômico e as instituições teriam papel central na disputa pela ordem internacional. Por seu turno, os construtivistas chamam a atenção da construção das ideias e seus impactos para a criação das instituições internacionais e de seu processo de tomada de decisão, que seguramente também representam poder (Barnett \& Duvall 2005). A imagem, os valores e a construção de identidades refletem bem essa característica difusa do poder pensado pelos construtivistas. 
2 As traduções são de responsabilidade dos autores $[\mathrm{NR}]$.
Nolte apresenta resumidamente como o poder é tratado nas principais vertentes das Teorias de Relações Internacionais:

\begin{abstract}
"Poder têm sido um conceito central da tradição realista das Relações Internacionais, e têm sido definido como o controle dos recursos - principalmente recursos militares. Outros autores tem definido poder como a relação entre dois atores (Estados), como nas definições de Joseph Nye. Poder pode ter um componente ideacional, como no conceito de autoridade usado por Lake ou no conceito de poder produtivo utilizado por Michael Barnett e Raymond Duvall" (Nolte 2010, p. 885) $)^{2}$.
\end{abstract}

Nesse sentido, a relação entre a Política Internacional e poder é relevante para as principais escolas das R.I., e a manifestação desse elemento é definidor da ordem vigente no Sistema Internacional. O conceito de ordem para Bull (2002) está ligado à compreensão da ordem para as sociedades nacionais. De maneira geral, o autor considera que poderíamos compreender o conceito de ordem da seguinte forma:

"[ao] afirmar que elas estão relacionadas entre si de acordo com uma certa estrutura; que a sua relação recíproca não é fruto puramente do acaso, mas contém algum princípio discernível. Assim, uma fileira de livros em uma estante exibe ordem, o que não acontece com um monte de livros amontoados no chão" (idem, p. 7).

Para o autor, a ordem na política internacional deve ser concebida como "padrões ou disposições da atividade humana que sustentam os objetivos elementares ou primários da vida social na humanidade considerada em seu conjunto" (idem, p. 26). Em primeiro lugar, Bull destaca o entendimento mais amplo de ordem, que diz respeito à existência de uma estrutura e de elementos dispostos nessa mesma estrutura que permite a compreensão de certa distribuição de poder. Dessa forma, a ordem social teria como fundamento três necessidades básicas dos seres humanos, em qualquer escala, que são: o direito à vida, de que as promessas sejam cumpridas e o direito à propriedade privada.

A ordem na Política Internacional também reflete em parte esses princípios, porém, a distribuição do poder no Sistema Internacional e o arranjo decorrente dessa mesma distribuição de poder relativiza a manutenção de alguns destes princípios, e levará à constituição de ordens distintas, favorecendo determinados Estados em detrimento de outros. A "pentarquia de poder" decorrente da ordem europeia após a era napoleônica, a bipolaridade na Guerra Fria, bem como a multipolaridade desbalanceada que o mundo experimenta no início do século XXI são exemplos de ordens internacionais distintas.

A Guerra Fria propiciou uma diminuição da relevância dos aspectos regionais em função da forte pressão gerada pelos grandes polos de poder do Sistema Internacional. De 1947 a 1989, União Soviética e Estados Unidos da América conseguiram conduzir grande parte da política internacional, deixando pouca margem de manobra para os demais atores. Isso significou que a maior parte da agenda internacional estava voltada para os embates "Leste-Oeste", em detrimento das questões lindeiras ou das relações regionais.

Com o fim dessa ordem, os Estados passaram a se preocupar com outras agendas e com outras escalas geográficas (Buzan 2003). Os problemas vivenciados pelos Estados a partir de então eram outros, e a geografia teria papel importante nessa readequação da ordem mundial. De certo modo, os problemas dos Estados não estavam restritos à possibilidade da "destruição mútua assegurada" entre os Estados Unidos e a União Soviética, mas sim, às relações comerciais entre os vizinhos, os seus problemas de fronteira e os novos desafios impostos pela agenda neoliberal. A ascensão do aspecto regional foi evidente a partir do fim da Guerra Fria, e isso trouxe impactos importantes para o entendimento da Política Internacional. 


\section{II.2. Potências médias tradicionais, emergentes e potências regionais}

Com o fim da Guerra Fria, os aspectos regionais e geográficos ganham força novamente. Os processos de integração regional, em especial os de caráter comercial, e a criação de uma série de blocos regionais, que se estendiam da bacia do pacífico às Américas, refletiam bem o impacto que o fim da Guerra Fria havia gerado à Economia Política Internacional. O ressurgimento de forças regionais relevantes, capazes de conter parcialmente movimentos econômicos e políticos de grandes potências, confirmou o início de uma nova ordem internacional, marcada por uma multipolaridade desbalanceada.

Dessa forma, é perceptível o aumento da relevância de atores intermediários no Sistema internacional. O papel das potências médias é resgatado por uma série de pesquisadores, que objetivavam compreender os impactos desses países para a nova realidade internacional. Para Jordaan (2010) é necessário diferenciar duas categorias de potências médias, as consideradas potências médias tradicionais e as potências médias emergentes. Essa diferenciação é importante pois o conceito de potência média envolveria uma quantidade grande de atores, incluindo realidades e papéis muito distintos. As potências médias tradicionais são caracterizadas por possuírem um Estado de Bem-Estar Social consolidado, que nasceram do centro de poder do Sistema Internacional após a II Guerra Mundial. São democracias constituídas e estáveis, além de serem países com baixo grau de desigualdade socioeconômico entre a população. Suas ações de política externa geralmente convergem com as ações das grandes potências ou da potência mundial, além de não se envolverem em questões regionais. Exemplos de potências médias tradicionais são Dinamarca, Suécia, Holanda, Austrália e Noruega.

Por outro lado, o conceito de potências médias emergentes é atribuído a alguns Estados após o fim da Guerra Fria. Esses países, ao contrário das potências médias tradicionais, pertenceriam à Semiperiferia do Sistema Internacional, possuindo características de países centrais, como economia pujante, crescimento econômico expressivo, mas também aspectos de países periféricos, como grande desigualdade social e pobreza. A democracia teria um caráter dúbio e instável, marcados por histórico de ditaduras e ações governamentais não democráticas. Outro aspecto importante é o papel regional que as potências médias emergentes possuem. Ao contrário das tradicionais, os emergentes possuem um ativismo regional evidente, muitas vezes buscando proeminência em sua zona de influência. Além disso, possuem um caráter reformista da ordem, isso é, buscam transformar a ordem internacional de maneira que as mudanças os beneficiem. Jordaan (idem) destaca que esse caráter reformista não possui um viés revisionista ou revolucionário, mas sim busca-se manejá-lo de maneira a criar condições mais adequadas aos seus projetos regionais e globais.

Já para Nolte (2010), o conceito de potência regional só pode ser compreendido a partir de duas categorias de análise: a geografia e o poder. "O tópico das potências medias é delimitado como uma linha de pesquisa que combina um conceito geográfico - região - com um conceito básico da Teoria de Relações Internacionais - Poder. Isso se refere a hierarquias de poder no Sistema Internacional" (idem, p. 885). Ainda para o autor, alguns aspectos são importantes para tentar distinguir as potências médias tradicionais e emergentes das potências regionais como:

“1) A dinâmica interna de um estado que deve permitir-lhe desempenhar um papel estabilizador e de liderança em sua região; 2) Tal estado deve indicar e demonstrar a sua vontade, e, claro, também a sua capacidade ou habilidade, para assumir o papel de líder regional, estabilizador e, se não for um peacekeeper, ao menos um peacemaking; 3 ) Deve ser aceitável para seus vizinhos - os membros 
do complexo de segurança em que atua - como um líder responsável pela segurança regional. A aceitação mais ampla, ou extra-regional é, talvez, uma condição necessária, mas não suficiente, mesmo se apoiado e promovido por grandes potências" (idem, p. 890).

Dessa forma, para Nolte (idem), os aspectos principais que diferenciam uma potência média emergente de uma potência regional é sua capacidade de liderança, seu reconhecimento local internacional como representante da área e seu caráter estabilizador. Porém, muitas vezes o conceito de potência média emergente se confunde com o conceito de potência regional. Para Huelsz (2009), a maior parte dos estudiosos da área consideram as potências médias emergentes também como potências regionais em função de sua proeminência econômica na região, bem como seu engajamento político como liderança regional. Mas como perceberemos no caso do Oriente Médio, em vários momentos não é possível destacar uma única potência regional em virtude do embate constante entre dois ou três atores regionais, com características de poder e atuações semelhantes.

\section{A Geografia do Oriente Médio}

Ao se iniciar qualquer empreitada em direção à definição do que vêm a ser o Oriente Médio, desde sua constituição geográfica até suas características históricas e étnico-religiosas, é importante ressaltar que as visões acerca dessa parte do mundo são diversas frente à multiplicidade de autores que tentam avaliar, cada um à sua maneira, os principais aspectos geohistóricos que caracterizam essa região do mundo.

Dessa forma, decidiu-se adotar o conceito desenvolvido por Zahreddine, Lasmar e Teixeira (2011) ao definirmos o que vêm a ser o Oriente Médio como região. De acordo com os autores, quatro macrocategorias auxiliariam o esforço de classificação do que vêm a ser o Oriente Médio: (i) as características físico-ambientais; (ii) a posição geográfica; (iii) A unidade geográfica; (iv) as características dos povos que ocupam a região. A partir dessas quatro categorias seria possível encontrar características comuns que nos permitiria classificá-la como uma região específica do mundo.

Com relação aos aspectos físicos-ambientais, duas características são mais notórias na região. A primeira diz respeito à escassez de água, mesmo com a presença de rios importantes que cortam aquela área, como o Nilo, o Eufrates, o Tigre e o Orontes. O segundo aspecto é a presença de desertos e do clima árido, que têm impacto direto sobre o modo de produção e o deslocamento das populações. A escassez da água, o clima extremo e a presença abundante de petróleo em grande parte dos países favorecem um traço singular àqueles Estados.

Já a posição geográfica diz respeito às características geradas pela relação existente entre a localização dessa região e sua vizinhança. Se olharmos com cuidado um mapa do Oriente Médio, perceberemos que ele está posicionado em uma área de conexão entre três continentes: Europa, Ásia e África. Essa característica reforçou historicamente a relevância dessa zona, considerada fundamental para conexão do comércio e do deslocamento de populações para os mais variados fins (militar, comércio, religião etc.).

Por sua vez, a unidade geográfica é dada pela presença de relevantes atributos geográficos nas extremidades daquela área, contornando uma extensa zona de terras desérticas, com alguns poucos vales ricos em água, como o vale do Nilo, do Tigre, Eufrates, o Vale do Bekka e o vale do Jordão. O limite norte da região seria feito pela presença dos Montes Taurus, na Turquia; ao sul, a península arábica com o mar da Arábia seria o limite meridional. A leste dos 
Montes Zagros, entre o Iraque e o Irã, residiria o limite oriental; e a oeste, o mar Mediterrâneo, o Nilo e o Hijaz saudita limitariam a borda mais ocidental da região.

A última categoria, as características dos povos, revela aspectos importantes da dinâmica geográfica e sociopolítica. É indiscutível a presença de dezenas de minorias étnico-religiosas, como os drusos, alauitas, judeus, armênios, curdos, cristãos maronitas etc., mas faz-se necessário ressaltar a importância da relação entre duas dimensões principais, que é a religiosa e a étnica. O Islamismo, bem como a relação existente entre árabes, persas, turcos e judeus historicamente afetaram as disputas pelo poder regional. Essas forças religiosas e nacionais também destacam um fator de diferenciação clara dessa região do mundo se comparada a outras áreas.

Além disso, é importante ressaltar que o papel da dinâmica regional e os impactos das ações políticas de um ator nos demais pertencentes à região revelariam muito das relações de interdependência dos integrantes dessa área. Esse é um conceito chave trabalhado por Buzan (2003), que se traduz nos Complexos de Segurança Regional. Esse conceito é importante pois demonstra o alto grau de interdependência dos Estados pertencentes a esse complexo de segurança, sendo a agenda de segurança um dos setores mais sensíveis para essa região. Dessa forma, um conflito que acomete um dos elementos desse subsistema regional, geraria impacto em toda área, e as prováveis soluções para os problemas regionais só poderiam ser resolvidos a partir de uma ação conjunta dos Estados.

Em virtude de todas as questões apresentadas anteriormente definimos a região do Oriente médio como:

"formado por quinze países e uma Autoridade Nacional Palestina, sendo eles: Turquia, Síria, Líbano, Israel, Palestina (Autoridade nacional e Território Ocupado), Egito, Jordânia, Arábia Saudita, Iêmen, Omã, Emirados Árabes Unidos, Bahrain, Catar, Kuwait, Iraque e Irã” (Zahreddine, Lasmar \& Teixeira 2011, p. 32).

Ainda do ponto de vista geográfico, as disputas regionais se mantêm muito em função da relação existente entre a abundância/escassez de dois recursos fundamentais, a água e o petróleo (Cleveland \& Bunton 2009). Geograficamente, a divisão entre os países com abundância de reservas de gás e petróleo e aqueles com um regime hídrico mais regular geraram sociedades distintas, e muitas disputas ocorrerão em função da extração desses dois recursos essenciais. Esse aspecto geográfico também deixa claro a importância que a região possui para o mundo, sendo essa área uma das maiores reservas e produtoras de petróleo do globo.

\section{As relações internacionais do Oriente Médio: breve perspectiva histórica}

\section{IV.1. O processo de independência e o início das disputas regionais}

A I Guerra Mundial influenciou diretamente o desenho territorial e político dos futuros Estados Nacionais do Oriente Médio. A vitória de Reino Unido e França, e as alianças estabelecidas durante e após a vitória da Tríplice Entente definiriam as futuras fronteiras da região. A aliança britânica com os árabes para desestabilizar o Império Turco Otomano, com a Revolta de 1916, e as promessas feitas aos Judeus, com a Declaração Balfour, em 1917, evidenciam as contradições das promessas feitas às forças locais no Oriente Médio e predizem as dificuldades futuras para solução dos conflitos locais.

Dessa forma, o fim da I Guerra Mundial gerou resultados contraditórios, pois ao mesmo tempo em que o Reino Unido prometia um Lar Nacional para os 
judeus, também sinalizava com a criação de um Estado Árabe forte. As promessas feitas aos judeus se concretizaram em 1947 com a Resolução 181 da Assembleia Geral das Nações Unidas, e em 1948, com a declaração unilateral de independência do Estado de Israel. Já para os árabes os resultados seriam ambíguos, pois as promessas feitas entre a autoridade britânica e a liderança árabe, por meio das cartas Hussein-McMahon, nunca foram concretizadas. Ao contrário de um grande Estado Árabe, que se estenderia do mediterrâneo à mesopotâmia, e do norte da Síria e Iraque à Península Arábica, o que se viu foi a criação de uma série de zonas de influências de franceses e britânicos, que ao final do entre-guerras forjariam as bases dos novos Estados Nacionais.

No período anterior à I Guerra Mundial, durante quase 300 anos, a ordem vigente nessa região seria regida pelas relações mantidas entre Egito, Império Turco Otomano e Pérsia (atual Irã). Com o fim da ordem turca após a I Guerra, e com a construção dessa nova ordem regional inaugurada por Reino Unido e França, muitos elementos da política e cultura otomana continuaram a existir, mas a criação de quase uma dezena de Estados Nacionais, com suas respectivas elites, tornou muito mais complexo o manejo das relações regionais.

\begin{abstract}
“O coração do Império Otomano estava fragmentado em seis estados: Turquia e cinco novos Estados, Síria, Líbano, Palestina Iraque e Transjordânia. Arábia Saudita e Iêmen também surgiram como entidades políticas distintas. Os três centros de autoridade foram expandidos para dez, cada um deles com suas próprias políticas domésticas e externas. Mas a política da maior parte destes novos estados eram determinadas pela ocupação europeia. Dos dez principais estados do Oriente Médio, somente Turquia, Irã, Arábia Saudita e Iêmen exerceram total soberania sobre seus estados, e as outras duas independências que vieram mais tarde foram autorizadas somente porque eram casos isolados, e porque Grã-Bretanha e França consideravam relativamente sem importância" (Cleveland \& Bunton 2009, p. 171).
\end{abstract}

Com o início do processo de independência dos Estados Árabes, principalmente a partir da década de 1940, a insistência das potências mandatárias em se manter na região gerou um ambiente de instabilidade. As disputas entre os principais atores regionais e a transição da ordem mundial da multipolaridade para a bipolaridade trouxe novos atores à cena, sendo França e Reino Unido substituídos pelos Estados Unidos e a União Soviética.

\title{
IV.2. O Oriente Médio e o prelúdio da ordem bipolar
}

Para algumas elites locais, a preservação da unidade nacional era fundamental para a manutenção de seus respectivos interesses, isto é, a defesa das soberanias locais era mais importante do que a busca por uma federação de Estados Árabes. Para outros, os processos de integração dos Estados em uma única unidade nacional seria o recurso necessário para a concretização dos sonhos de uma unidade territorial árabe capaz de representar seu verdadeiro legado histórico.

Em razão dessas duas perspectivas dominantes, uma série de alianças serão formadas com o intuito de defender seus respectivos projetos. A posição da Arábia Saudita era de preservação da soberania nacional, enquanto Jordânia e Síria buscaram implementar projetos de integração regional.

As diferentes posições das elites locais geraram um dilema acerca das visões universalistas ou soberanistas entre os Estados Árabes. Em virtude disso, uma série de encontros foram organizados com o intuito de buscar uma saída para o dilema. As conversações iniciaram-se de maneira mais efetiva a partir de 1943, estendendo-se para os anos de 1944 e 1945. Em 7 de outubro de 1944 um primeiro avanço importante para uma solução consensual foi alcançada, com a 
aprovação do Protocolo de Alexandria, que significou o primeiro passo para a formação de uma Liga dos Estados Árabes.

“A proposta básica era que uma Liga Árabe seria formada por Estados Árabes independestes para consolidar os laços inter-árabes, [criar] planos de coordenação política, proteção à soberania dos Estados membros contra agressões, e supervisão das relações dos Estados Árabes. Também foi estipulado que os Estados membros estavam proibidos de adotar políticas externas prejudiciais à liga ou aos seus Estados membros" (Taylor 1982, p. 23).

Finalmente, em 10 de maio de 1945, a Liga Árabe é formalmente criada. Ela era na verdade uma organização regional fraca, mas que desempenharia papel relevante como veículo para cooperação nos campos político, econômico e cultural nas relações inter-árabes. Ela também buscaria preservar a soberania dos Estados membros, e não assumiu as restrições colocadas pelo Protocolo de Alexandria acerca da condução da política externa dos Estados (idem).

As décadas de 1940 e 1950 foram marcadas pelos processos de independência e pelos movimentos que buscavam institucionalizar essa nova realidade. A criação da Liga Árabe foi um passo importante para esse momento, porém, persistia ainda um problema antigo, o papel desempenhado pelas antigas potências mandatários na política das recentes repúblicas e monarquias do Oriente Médio. Nesse sentido, uma série de transformações políticas ocorrerão na região, fruto das acomodações internas, das disputas regionais e mundiais. Um momento fundamental que expressa essas transformações foi a revolta egípcia. No Egito, a atuação de um grupo de militares conhecidos como Oficiais Livres retiram do poder o Rei Faruk em 23 de julho de 1952. As relações com o Reino Unido se tornam mais difíceis com a ascensão do Presidente Gamal Abdel Nasser ao poder e a posterior nacionalização do Canal de Suez. A resposta inglesa, responsável pela administração do canal, foi uma intervenção militar, com o apoio francês e israelense em 1956, conhecida como guerra do Canal de Suez.

Esse momento é importante para a região pois representará a última tentativa de manutenção da ordem regional pelos europeus. Os resultados da guerra foram favoráveis ao governo egípcio, devido à condenação veemente feita por Estados Unidos e União Soviética acerca da intervenção militar. A malfadada operação militar representou o enfraquecimento inglês e francês na ordem regional e trouxe à cena aqueles dois novos atores.

Um dos principais desdobramentos da Guerra de 1956 foi o crescimento do nacionalismo árabe, representado pelo Pan Arabismo. Esse movimento, liderado pelo próprio presidente Nasser, significou a tentativa de aliança entre os países árabes na busca de uma alternativa mais adequada ao desenvolvimento da região (Seddon 2004). Vários foram os desdobramentos do aumento do

${ }^{3}$ União entre Egito e Síria que perdurará de 1958 a 1961. nacionalismo árabe, entre eles, a criação da República Árabe Unida ${ }^{3}$ (RAU) em 1958, o aprofundamento das disputas regionais e o acirramento da tensão entre Israel e o mundo árabe.

Após a Guerra dos Seis dias, em 1967, e a morte do presidente egípcio Gamal Abdel Nasser, em 1970, uma nova fase de alinhamentos é inaugurada. O impacto da derrota na guerra e a perda de uma figura emblemática como Nasser permitiu uma postura mais pragmática do governo egípcio junto ao governo saudita e à Síria. O objetivo seria criar as condições ideais para pressionar Israel a devolver os territórios capturados na Guerra de 1967. Essa aliança ficou conhecida como a aliança "trilateral”, entre Egito, Síria e Arábia Saudita (Taylor 1982):

"A aliança trilateral foi o produto da tendência pragmática na política árabe que havia começado a se desenvolver após a guerra de 1967. Tanto al-Sadat e al Assad, como os respectivos líderes dos maiores e mais fortes estados envolvidos 
no confronto, estavam mais preocupados com a coordenação de esforços para recuperar os territórios ocupados do que com questões ideológicas" (idem, p. 51).

A Guerra do Yon Kippur, em 1973, representou o esgotamento das alternativas pacíficas para resolução dos dilemas gerados na Guerra de 1967 e a frustração egípcia com a incapacidade estadunidense de pressionar Israel a negociar. A participação da Arábia Saudita na Aliança Trilateral teria papel importante como fonte de financiamento ao projeto político dos três Estados. A crise do Petróleo de 1973 é um bom exemplo da função desempenhada pela Arábia Saudita, no intento de pressionar o mundo a observar os dilemas vivenciados pelos árabes.

As décadas de 1950 e 1960 representaram o auge do papel político do Egito no arranjo de poder no Oriente Médio. O início da década de 1970, já sob o comando do Presidente Anwar al Sadat, o Egito se transforma de uma grande força que pressionava Israel a negociar a paz com os árabes, para um ator que assume uma política externa mais tímida, isolacionista, abrindo espaço para atuação de outras potências médias na região.

A nova postura egípcia, de busca de um acordo de paz com Israel, e de aproximação estratégica com os Estados Unidos gerou impacto direto no sistema árabe. Vários países se colocaram contra a postura egípcia, como Síria, Líbia, Argélia e Iêmen do Sul. Outro grupo de países, conhecidos como "bloco silencioso", não se manifestava claramente com relação ao problema. Arábia Saudita, Kuwait, e Jordânia eram alguns de seus integrantes. Os favoráveis à política egípcia eram Sudão, Marrocos e Omã (idem).

Já ao final da década de 1970, e com a visita do presidente Sadat a Jerusalém para propor um acordo de paz aos israelenses, intensificam-se as posições contra o Egito, sendo que Síria, Iraque e Jordânia começam a pressionar de maneira mais veemente o movimento egípcio. O principal dilema criado pelos egípcios foi a decisão unilateral de buscar a paz com os israelenses, não levando em conta a possibilidade de um acordo mais amplo, que incluísse os palestinos e os Sírios. Isso representaria um dilema para a unidade e solidariedade entre os árabes, e os esforços sauditas nesse momento era de não permitir uma fragmentação política ainda maior entre os Estados da região.

Ao mesmo tempo em que os egípcios se retiram do centro da vida política do Oriente Médio e do sistema árabe, Síria e Iraque iniciam um processo de aproximação em função de uma agenda importante para ambos os países. A aliança entre Iraque e Síria colocaria em jogo o papel de grandes forças, como os egípcios e os sauditas. A junção de dois países com populações consideráveis, bem armados com tecnologia soviética e financiados com a expressiva reserva petrolífera iraquiana tornava a aliança um elemento importante para o equilíbrio de poder do sistema árabe. Porém, as rivalidades históricas entre os dois Estados, bem como a constituição étnico-religiosa de ambos seria um obstáculo para o sucesso da aliança.

A decisão unilateral egípcia de buscar um acordo de paz com Israel sem levar em consideração um acordo mais amplo, que incluísse, além dos palestinos, os países árabes que tiveram perdas territoriais em guerras, gerou um movimento de fortalecimento da posição iraquiana, muito crítica à posição egípcia.

Outro elemento importante para a compreensão do novo ordenamento de forças que se cria no Oriente Médio a partir de 1979 é a Revolução Islâmica no Irã. A derrubada do Xá e a tomada do poder pelo Aiatolá Khomeini gerou uma preocupação generalizada, principalmente entre os países do golfo pérsico e as monarquias. Arábia Saudita e Jordânia uniram-se aos esforços iraquianos com o 
intuito de limitar os desdobramentos da revolução iraniana. Nesse momento, o Iraque surge como clara liderança no sistema árabe, suplantando os egípcios (idem).

Dessa forma, a Revolução Iraniana teve papel fundamental nas transformações políticas da última década da Guerra Fria. O realinhamento iraquiano a favor dos Estados Unidos e a defesa do arabismo sunita contra os persas xiitas é bem representativo dos desdobramentos que a região experimentará. A partir dessa posição de força dos iraquianos, outro eixo de contenção à presença estadunidense será formado, representado pela aliança Síria-Líbia, com viés pró-URSS. As disputas regionais serão fortemente condicionadas pelo antagonismo Leste-Oeste, e pelos contenciosos regionais, representativos dos projetos iraquiano, saudita e egípcio de um lado, e das ambições de expansão da revolução islâmica para o golfo pérsico e restante do Oriente Médio, pelo Irã.

A guerra Irã-Iraque representou em um primeiro momento a preocupação de grande parte dos países árabes com a expansão da revolução xiita para o restante da região. Nesse cenário, Saddam Hussein surge como um elemento importante para esses países, como defensor da estabilidade regional e contrário a um projeto de expansão persa pelos países árabes. $\mathrm{O}$ apoio saudita e dos reinos do Golfo Pérsico à empreitada iraquiana contra o Irã permitirá, ao menos em médio prazo, a confirmação da liderança iraquiana do mundo árabe. Porém, com o revés da guerra e a rápida recuperação das forças iranianas, as dificuldades econômicas e o aumento da divisão do mundo árabe com relação ao papel desempenhado pelo Iraque forçam novos arranjos na política regional. $\mathrm{O}$ fim da Guerra Irã-Iraque coincidirá com os últimos anos da Guerra Fria, e uma realidade completamente nova surgirá a partir de então, e impactos importantes serão percebidos a partir de 1990.

IV.3. O início de uma nova ordem internacional - Os anos 1990

As transformações ocorridas no início da década de 1990 na ordem mundial permitiu também que mudanças profundas ocorressem no Oriente Médio. O fim das disputas entre Estados Unidos e União Soviética e a evidente supremacia militar dos estadunidenses gerou uma sensação de que o mundo seria regido por uma ordem unipolar. O fim da Guerra Irã-Iraque, em 1988, e os impactos que ela gerou para a economia e infraestrutura iraquiana pode ter sido um dos fatores que levaram o presidente Saddam Hussein a iniciar um contencioso sério com o seu país vizinho, o Kuwait.

A primeira Guerra do Golfo é fundamental para compreender a ordem regional do Oriente Médio na era pós-Guerra fria, pois seus resultados geram mudanças importantes nas relações internacionais da região. Até então, o papel iraquiano como nova liderança do mundo árabe, após a retração egípcia em seu engajamento regional, será transformado, em função dos resultados da intervenção internacional liderada pelos Estados Unidos em 2 de agosto de 1990. Os resultados da intervenção foram desastrosos para o papel iraquiano no sistema árabe e para a ordem regional. A destruição da capacidade militar iraquiana, bem como a imposição de pesadas sanções econômicas ao país, geraram uma degradação gradativa da capacidade político-militar daquele Estado, bem como de sua capacidade de ordenar as relações entre os atores regionais (Fawcett 2005).

O papel do Egito e da Arábia Saudita ao apoiar a intervenção militar é muito importante nesse contexto, pois demonstra mais uma vez a relevância destes atores históricos para o ordenamento regional. Em 28 de fevereiro de 1991, um cessar fogo é aceito pelos Estados Unidos. Os resultados da empreitada são dúbios, pois mesmo com a vitória militar contra os iraquianos o presidente 
Saddam Hussein não é destituído de seu posto, o que gerará, no transcorrer da década de 1990, outros contenciosos com a superpotência. O papel estadunidense se fortalece na região e as relações entre Estados Unidos e Egito, Arábia Saudita e os Emirados do Golfo se desenvolvem. Os pontos de tensão na região continuam sendo o conflito Palestino-Israelense e a postura contra-hegemônica iraniana e síria. Várias outras crises acontecerão durante a década de 1990, dentre elas destaca-se a difícil relação entre Israel e Líbano, que gerou várias operações militares contra o Hizballah e o Líbano.

Ao mesmo tempo, avanços importantes foram alcançados em 1993, com a assinatura dos Acordos de Oslo entre Israel e os palestinos. Esforços foram empreendidos por ambas as partes, com mediação do governo estadunidense e das Nações Unidas, com o intuito de criar condições para o término das hostilidades entre palestinos e Israelenses (idem). Os primeiros anos de implementação do acordo foram promissores, mas o posterior assassinato do primeiro ministro israelense Ytzak Rabin por um fundamentalista judaico iniciou um novo ciclo de violência, o que gerou resultados negativos para o início do século XXI.

IV.4. Os atentados de 11 de setembro de 2001

As relações internacionais do Oriente Médio após os atentados de 11 de setembro continuam sendo tema de muitas discussões. Os ataques contra as Torres Gêmeas precipitou uma série de ações político-militares que tiveram impacto direto no mundo árabe e no Oriente Médio como um todo. A ação militar contra o Afeganistão em 7 de outubro de 2001 e a segunda invasão do Iraque em 20 de março de 2003 geraram mais uma vez fortes disputas pelo controle da ordem regional. $\mathrm{O}$ fortalecimento dos aliados estadunidenses e o enfraquecimento de países que historicamente resistiam à presença estrangeira, como Irã e Síria, levou a uma maior desestabilização da região. Além disso, a presença de atores transnacionais, como grupos terroristas, tornaram ainda mais complexo o cenário regional.

A destituição do governo talibã no Afeganistão e a entrada das forças militares estadunidenses naquele país tornou ainda mais instável as relações políticas na sociedade afegã. A presença militar estrangeira que durou de 2001 a 2014 geraria um embate constante entre os clãs e grupos transnacionais, que atuariam no tráfico de drogas, ataque às forças estrangeiras e a partes da sociedade afegã que apoiava a presença das forças de intervenção. O quadro de instabilidade no Afeganistão afetou de maneira direta o país vizinho, o Paquistão, que também sofreu com atentados terroristas constantes.

A segunda Guerra do Golfo, iniciada em 20 de março de 2003, também geraria resultados semelhantes. Com a destituição do presidente Saddam Hussein e de toda sua cúpula, as disputas existentes entre curdos, sunitas e xiitas que eram contidas pelo governo vieram à tona (Zahreddine 2003). Um cenário de extrema instabilidade tomou conta do país, culminando com a participação de grupos transnacionais formados por fundamentalistas islâmicos, como a $\mathrm{Al}$ Qaeda e o Estado Islâmico do Iraque e do Levante (EIIL), controlando partes significativas do território iraquiano. A retirada das forças estrangeiras do Iraque aprofundaram ainda mais o cenário de crise, permitindo uma atuação ainda mais forte de grupos terroristas.

Um aspecto importante a ser destacado no período posterior a 11 de setembro de 2001 são os efeitos das intervenções estrangeiras para a ordem regional. no célebre discurso do presidente Bush acerca do "eixo do mal", de 29 de janeiro de 2002, ele indica a disposição em conter e, se necessário, destruir, países que, para ele, financiavam o terrorismo internacional e eram portadores de 
armas de destruição de massa. Tais países significavam um risco para os Estados Unidos, e portanto, deveriam ser combatidos com veemência. O interessante da postura estadunidense é que todos os países citados como pertencentes ao eixo do mal eram na verdade regimes contrários à presença ativa estadunidense na política regional. Iraque, Irã, Líbia e Síria são os representantes no Oriente Médio do eixo do mal e, coincidentemente, países que mais resistiam à intervenção estadunidense na região.

A invasão do Iraque e do Afeganistão na gestão do presidente Bush gerou um efeito contrário ao esperado, pois já no início de 2010 percebia-se claramente a impossibilidade de solução do problema iraquiano sem o auxílio do Irã e, ao mesmo tempo, as intervenções militares geraram um maior grau de imprevisibilidade da ordem regional, marcada pela difusão de grupos armadas transnacionais no Iraque, Síria e Afeganistão.

A primavera árabe iniciada em dezembro de 2010 na Tunísia também criou desdobramentos importantes para a ordem vigente. A difusão de uma série de rebeliões e protestos por toda a região gerou resultados distintos. A deposição de Ben Ali na Tunísia e de Mubarak no Egito demonstraram a força do movimento social árabe. $\mathrm{O}$ assassinato de kadafi na guerra civil líbia geraria desdobramentos importantes para as relações entre Estados Unidos e Rússia no Oriente Médio. E a guerra civil na Síria tem exposto toda a complexidade das disputas locais, regionais e internacionais, levando a um prognóstico não muito positivo sobre a região (Zahreddine 2011).

As relações entre israelenses e palestinos se mantiveram tensas e o apoio incondicional estadunidense à política externa israelense aumentou ainda mais a ferocidade dos grupos islâmicos envolvidos na luta armada no Iraque e na Síria. A manutenção de Israel como grande força militar no Oriente Médio pelo apoio incondicional estadunidense aprofundou a instabilidade regional. Confrontos entre Israel e Hizballah continuaram nesse período, sendo a guerra de 2006 o evento mais importante desde a retirada israelense do Líbano em 2000. Em 2014, a campanha militar israelense contra a Faixa de Gaza reforçou ainda mais as posições de grupos fundamentalistas islâmicos na luta contra Israel, Estados Unidos e seus aliados europeus.

Em suma, desde os atentados de 11 de setembro o Oriente Médio continuou marcado pela tensão e violência, e a instabilidade não dá sinais de acabar. O Irã, apoiado pela Rússia e pela China, e a Arábia Saudita, apoiada pelos Estados Unidos, mantêm uma disputa acirrada pela região, sinalizando o papel importante de velhos atores para a ordem vigente naquela área.

\section{Resultados}

As duas questões principais que buscamos responder neste artigo dizem respeito à relevância que os atentados de 11 de setembro de 2001 tiveram para o ordenamento político do Oriente Médio, bem como avaliar quais foram os atores estatais mais importantes para a região. Para responder a essas perguntas, decidiu-se, em primeiro lugar, identificar quais foram os principais atores regionais do Oriente Médio, a partir de uma análise temporal, avaliando as décadas de 1980, 1990, 2001 (atentados de 11 de setembro) e 2010. Foram utilizados os conceitos de Nolte (2010), Huelz (2009) e Jordaan (2010) para classificar que tipo de potências seriam cada país. Além disso, utilizaremos de dados do Banco Mundial que reflitam minimamente características de poder real e potencial dos Estados. Dessa forma, avaliou-se se no decorrer das décadas ocorreram mudanças relativas às potências regionais. Por fim, analisa-se se os atentados de 11 de setembro de 2001 geraram mudanças significativas na 
configuração de poder da região. Foi aplicado o método de Análise de Componentes Principais (ACP) para criar uma hierarquia de poder para região.

O papel das potências regionais como força de estabilização e promotora de ordem regional é o que as diferencia das potências médias. Em nosso caso, o mais importante seria identificar quais seriam os atores estatais que se enquadrariam como potências regionais no transcurso das décadas, principalmente após os atentados de 11 de setembro. Para isso, iremos avaliar os seguintes quesitos, levando em consideração os conceitos tratados pelas teorias de potência:

- Poder real (PIB, efetivo militar e gasto militar);

- Poder potencial (população, área do país, produção de energia e consumo de energia);

- Poder ideacional (participação em instituições internacionais);

- Ativismo regional;

- Reconhecimento regional;

- Papel estabilizador.

Reconhecemos que existe certo grau de arbitrariedade na escolha desses quesitos, bem como das variáveis quantitativas que representariam o poder real e o poder potencial, como forma de avaliação da capacidade regional de um determinado estado. Porém, esse estudo representa um primeiro esforço em avaliar as transformações da ordem regional do Oriente Médio e seus resultados poderão sofrer mudanças no transcurso do tempo. De qualquer forma, os resultados alcançados neste estudo auxiliarão esforços para encontrar uma medida adequada para a análise histórica e para o tratamento estatístico dos dados.

A hipótese é que, na esfera do poder material, os países que estiveram à frente das disputas geopolíticas na região se mantiveram os mesmos, inclusive após os eventos de 11 de setembro de 2001. Utilizou-se como referência quatro atores regionais que frequentemente são tratados pela bibliografia especializada (apresentada em nossa seção histórica) para balizar os resultados quantitativos do estudo. Dessa forma, nas tabelas abaixo, serão destacados em cores distintas os seguintes países: Arábia Saudita, Egito, Irã e Turquia. Perceberemos que nos dados apresentados ocorrerão algumas oscilações na posição desses quatro atores entre os 16 países pertencentes ao Oriente Médio, mas em quase todos os quesitos analisados esses Estados aparecem com posições importantes no sistema regional.

V.1. Poder real

O poder real é uma definição trabalhada por vários autores da escola realista das Relações Internacionais. Tanto Waltz (2002) quanto Mearsheimer (2001) avaliam o papel das forças militares para a projeção de poder de um Estado. Para o institucionalismo neoliberal, a economia seria a força motriz que permitiria a constituição de uma força armada capaz de se projetar internacionalmente. Dessa forma, decidiu-se escolher três variáveis que representariam minimante esse debate, que seriam: (i) o tamanho do efetivo militar; (ii) o gasto militar e (iii) o Produto Interno Bruto (PIB) dos Estados da região.

De acordo com a Tabela 1 (tamanho do efetivo militar), percebe-se uma pequena oscilação ao passar dos anos escolhidos para análise. Não foi possível apresentar os dados de 1980 pela inexistência de informação acerca desse 


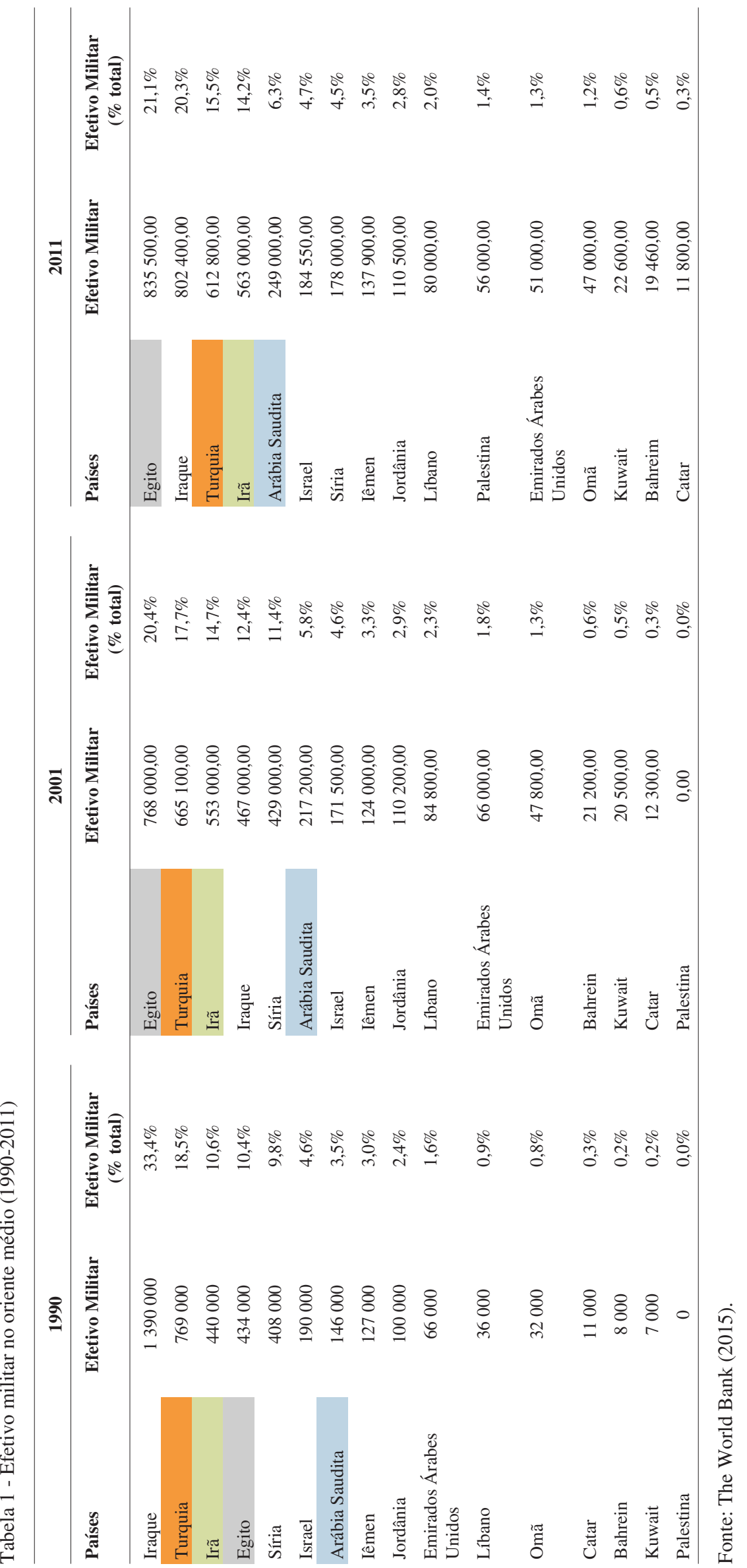


${ }^{4}$ As fontes utilizadas do Banco Mundial, referente aos anos de 1980, 1990, $2001 \mathrm{e}$ 2011, em todas as tabelas subsequentes, são do World Data Bank: World Development Indicators (The World Bank 2015) quesito nos bancos de dados trabalhados. Tanto o Banco Mundial ${ }^{4}$, quanto o Stockholm International Peace Research Institute (SIPRI), centros importantes que fornecem seus bancos de dados para consulta pública, não apresentam dados sobre o ano de 1980 acerca das questões militares apresentadas neste artigo.

O interessante desse dado é que ocorre uma pequena oscilação nas posições entre os anos de 1990 a 2011, sendo mais interessante as transformações ocorridas entre 2001 e 2011. O aumento significativo nas forças iraquianas e egípcias entre esses dois anos pode ser o efeito da política de reforço estadunidense da sua luta contra o terrorismo na região (política adotada após os atentados de 11 de setembro). Com a derrubada do governo de Saddam Hussein, em 2003, a recomposição das forças militares daquele país foi feita sob os auspícios do governo estadunidense, o que permitiu uma retomada considerável do efetivo militar iraquiano. Já o caso egípcio, até o início da primavera árabe em 2010-2011, também contava com generoso auxílio estadunidense para a composição de suas forças armadas, haja vista o aprofundamento das relações entre estes dois países desde a assinatura dos acordos de Camp David em 1978 com Israel.

A Tabela 2 também reforça o papel desses quatro países para a região. Durante os três períodos escolhidos, a Arábia Saudita surge com o maior orçamento militar entre os 16 países analisados, alcançando $35,2 \%$ de todo o gasto militar da região em 1990 (somando os gastos de todos os países do Oriente Médio). A oscilação dos demais atores regionais demonstram os impactos do preço do petróleo para o financiamento dos gastos militares bem como das instabilidades regionais que forçaram um maior gasto militar em determinados anos, como a primeira Guerra do Golfo (aumento do gasto militar do Kuwait) e o conflito palestino-israelense.

Como último indicador de poder real, o PIB tem papel importante nas discussões sobre poder, pois representa toda a riqueza produzida por um país e de certa forma, revela de maneira adequada a pujança econômica e o tamanho de sua economia. A capacidade de transformar poder econômico em poder militar faz da economia uma força motriz importantíssima, logo, surge como um dos elementos definidores da inserção regional de um país para sua região.

A Tabela 3 demonstra novamente a reincidência de três atores importantes para o aspecto econômico da região. Arábia Saudita, Irã e Turquia aparecem como as principais forças econômicas nos anos de 1980, 1990, 2001 e 2011. Arábia Saudita se destaca pela extração e produção de petróleo, sendo que seu PIB reflete principalmente a prospecção, refino e exportação desse hidrocarboneto. Já a Turquia, que possui pouco recurso petrolífero, mantém uma economia forte em função de sua indústria. Por sua vez, o Irã mescla a produção e exportação de sua vasta reserva petrolífera com um parque industrial relevante. Desde o fim da era Nasser no Egito, esse país experimentou um forte retraimento da política regional, principalmente após a guerra de 1973. Isso refletiu também em sua política econômica, que diminuiu significativamente sua importância na região. Israel, em função de sua indústria de alta tecnologia, e do apoio externo recebido principalmente da diáspora judaica e do governo estadunidense, manteve presença importante no cenário econômico. Em 2001 Israel era a terceira economia da região, caindo para o quinto lugar em 2011.

Como bem colocado na história das relações internacionais do Oriente Médio, o papel do Iraque ao final da década de 1970 e na década de 1980 foi muito importante em função do retraimento egípcio e do apoio estadunidense para a contenção da revolução iraniana. Isso fica evidente no PIB iraquiano de 1980, bem como no tamanho de seu exército em 1990. Infelizmente não temos os dados de gastos militares do Iraque para os anos de 1990 e 2001, em função do estado de guerra mantido com as potências ocidentais. Em 2011 o Iraque 


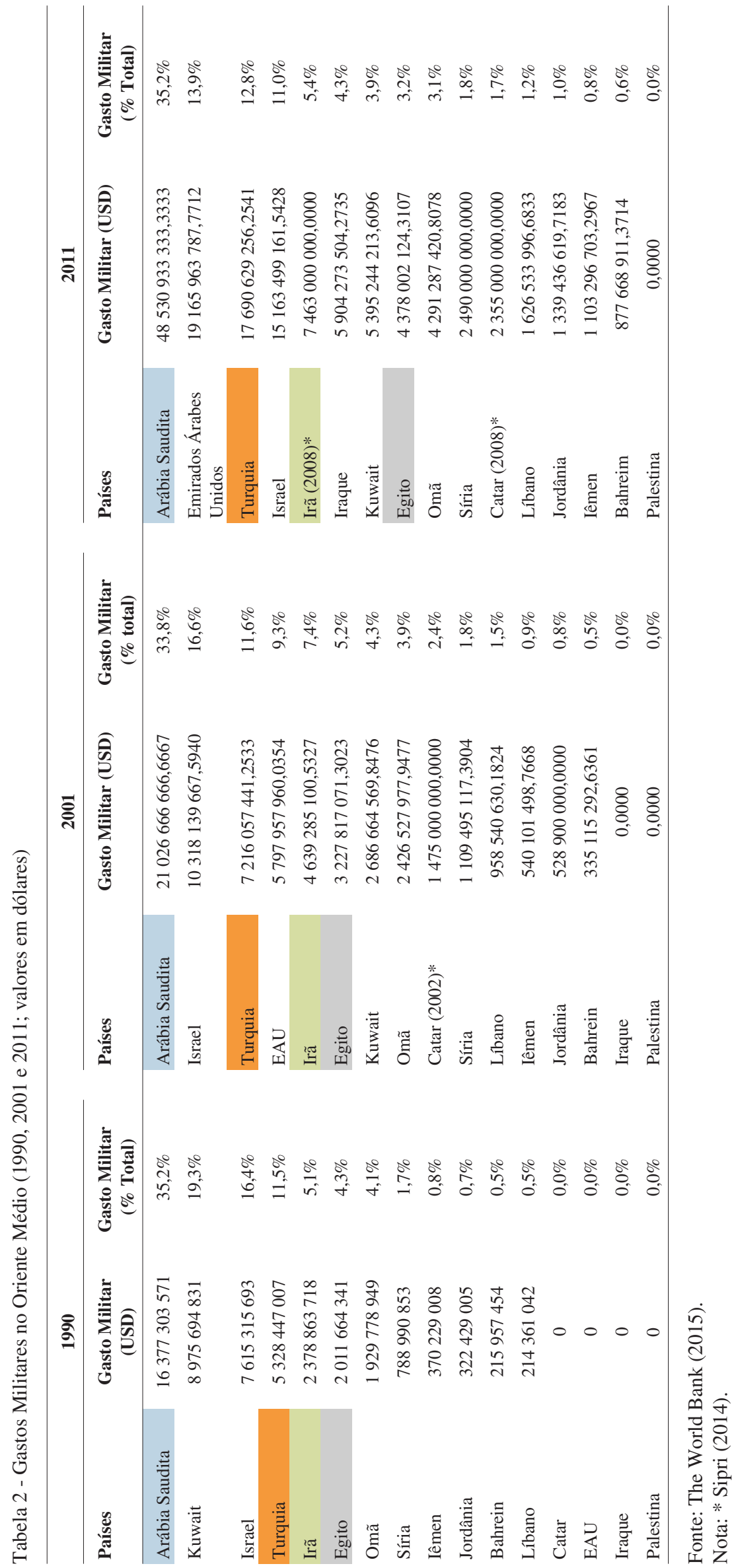







volta a ter um significativo gasto militar em função do apoio estadunidense após a derrubada do regime de Saddam Hussein. O papel de Israel também é relevante no cenário regional, mas a principal razão para a projeção de força regional de Israel está mais ligado ao apoio do mundo ocidental à sua política e os acordos de cooperação tecnológica mantida com vários aliados ocidentais do que com o processo de inserção regional propriamente dito.

Em suma, é importante destacar o papel de Arábia Saudita, Irã e Turquia no cenário militar e econômico da região e observar como esses atores se mantiveram ativos no cenário regional nos últimos 40 anos. Se observarmos as cores que representam estes países perceberemos que em todos os quesitos apresentados eles surgem entre as cinco primeiras posições, e muitas vezes entre as três primeiras.

\section{V.2. Poder potencial}

O poder potencial de um Estado significa a possibilidade de conversão de elementos de capacidade em poder, isto é, existe a necessidade de desenvolvimento de recursos e tecnologias para o emprego do poder. A simples posse desse elemento de poder não é garantia que ele pode ser transformado em poder real. Uma população numerosa só poderá significar um elemento de poder para um determinado Estado se ela possuir características de educação formal, de capacidade de consumo, de habilitação para trabalhos complexos ou preparo para o serviço militar, caso contrário, uma população numerosa poderá significar um estorvo e não uma característica de poder para o Estado. Quatro variáveis são destacadas: (i) superfície territorial do Estado; (ii) tamanho de sua população; (iii) produção de energia e (iv) consumo de energia.

Uma grande superfície territorial que não tenha uma boa distribuição espacial de sua população, de sua indústria ou de suas forças armadas talvez não signifique necessariamente um ponto forte para o Estado. A probabilidade de se encontrar recursos naturais de valor e utilizar de maneira tática a profundidade de um grande Estado são vantagens que dependem da capacidade dos governos prospectarem os recursos e utilizarem de maneira adequada seus atributos espaciais.

A Tabela 4 apresenta as maiores extensões territoriais do Oriente Médio, que coincidentemente equivalem aos quatro atores mais ativos da região nas últimas quatro décadas. Mesmo com a escassez de água e de terra agricultável em quase todos os quatro países, a presença de um extenso território permitiu o aumento da probabilidade de se encontrar recursos naturais estratégicos e de utilizar estrategicamente sua dimensão espacial para fins táticos. É claro que o tamanho do território não é garantia de um Estado poderoso, haja vista o papel de Israel e dos Emirados Árabes Unidos, que mesmo possuindo um diminuto Estado territorial utilizam de suas vantagens políticas ou energéticas a seu favor.

O mesmo exemplo pode ser utilizado para entender o papel do tamanho de uma população como um elemento de poder. Se um Estado possui um grande contingente populacional, que tenha um bom nível de educação formal, com capacidade para o consumo, com mão de obra treinada e adequada para trabalhos fundamentais e complexos, bem como aptidão para o serviço militar, essas qualidades tornam o número de habitantes um elemento de poder importante. Por outro lado, uma grande população de famintos e desabrigados não colaboraria para o poder nacional. É nesse sentido que devemos pensar o papel das populações como um elemento de poder potencial.

A Tabela 5 apresenta novamente o protagonismo dos quatro países analisados no decorrer desse artigo. Egito, Irã, Turquia e Arábia Saudita estão entre as 
Tabela 4 - Superfície em km² no Oriente Médio (2011)

\begin{tabular}{lcc}
\hline Países & Área $\left.\mathbf{( k m}^{2}\right)$ & Área (total) \\
\hline Arábia Saudita & 2149690 & $29,1 \%$ \\
Irã & 1745150 & $23,6 \%$ \\
Egito & 1001450 & $13,6 \%$ \\
Turquia & 783560 & $10,6 \%$ \\
Iêmen & 527970 & $7,2 \%$ \\
Iraque & 438320 & $5,9 \%$ \\
Omã & 309500 & $4,2 \%$ \\
Síria & 185180 & $2,5 \%$ \\
Jordânia & 88780 & $1,2 \%$ \\
Emirados Árabes Unidos & 83600 & $1,1 \%$ \\
Israel & 22070 & $0,3 \%$ \\
Kuwait & 17820 & $0,2 \%$ \\
Catar & 11610 & $0,2 \%$ \\
Líbano & 10450 & $0,1 \%$ \\
Palestina & 6020 & $0,1 \%$ \\
Bahreim & 690 & $0,0 \%$ \\
\hline
\end{tabular}

Fonte: The World Bank (2015).

cinco maiores populações do Oriente Médio. Em 2011, a população total do Oriente Médio era de 373 milhões de habitantes, sendo que a soma das populações destes quatro países equivalia a quase $70 \%$ de toda a população da região. Essa dilatada população, para realidade local, permite que estes países formem exércitos com grandes contingentes militares e se tornem uma força geodemográfica importante para as relações militares e comerciais. Coincidentemente, esses países estão localizados em zonas de contato com outros continentes. A Turquia conectando a Europa ao Oriente Médio, o Egito ligando a África ao Oriente Médio e o Irã demarcando o limite entre o Oriente Médio e a Ásia Central. A conexão geográfica favoreceu o comércio e a presença de um maior contingente populacional nesses três países.

O motor de qualquer economia nacional é alimentado pela capacidade de produção ou importação de energia. Dessa forma, a pujança econômica está ligada às necessidades de consumo de energia e à sua produção nacional. A busca pela autossuficiência energética é um caminho importante para a reafirmação de uma economia e país forte. Dessa forma, buscamos mostrar como a produção e o consumo de energia se dá no Oriente Médio. Sem dúvida alguma, a produção energética nessa região do mundo estará intimamente ligado à presença das grandes reservas petrolíferas.

Nem todos os países da região possuem reservas consideráveis de petróleo, e isso fica claro nos resultados apresentados. O consumo de energia representa duas características principais: (i) a necessidade de responder ao consumo da população, como calefação ou refrigeração, uso doméstico, transporte público etc.; (ii) responder à necessidade de consumo das indústrias e grandes empresas. Dessa formam há de se esperar que o consumo de energia seja maior em Estados com grande população ou com forte atividade industrial.

A Tabela 6 revela essa divisão entre países produtores de petróleo e aqueles que não possuem quase nenhum recurso energético. Em 2001 e 2011, de toda energia produzida na região, Arábia Saudita e Irã foram responsáveis por 50\% do total produzido. Emirados Árabes Unidos, Catar, Iraque e Kuwait, todos países do Golfo Pérsico, também são grandes produtores de energia, em função 


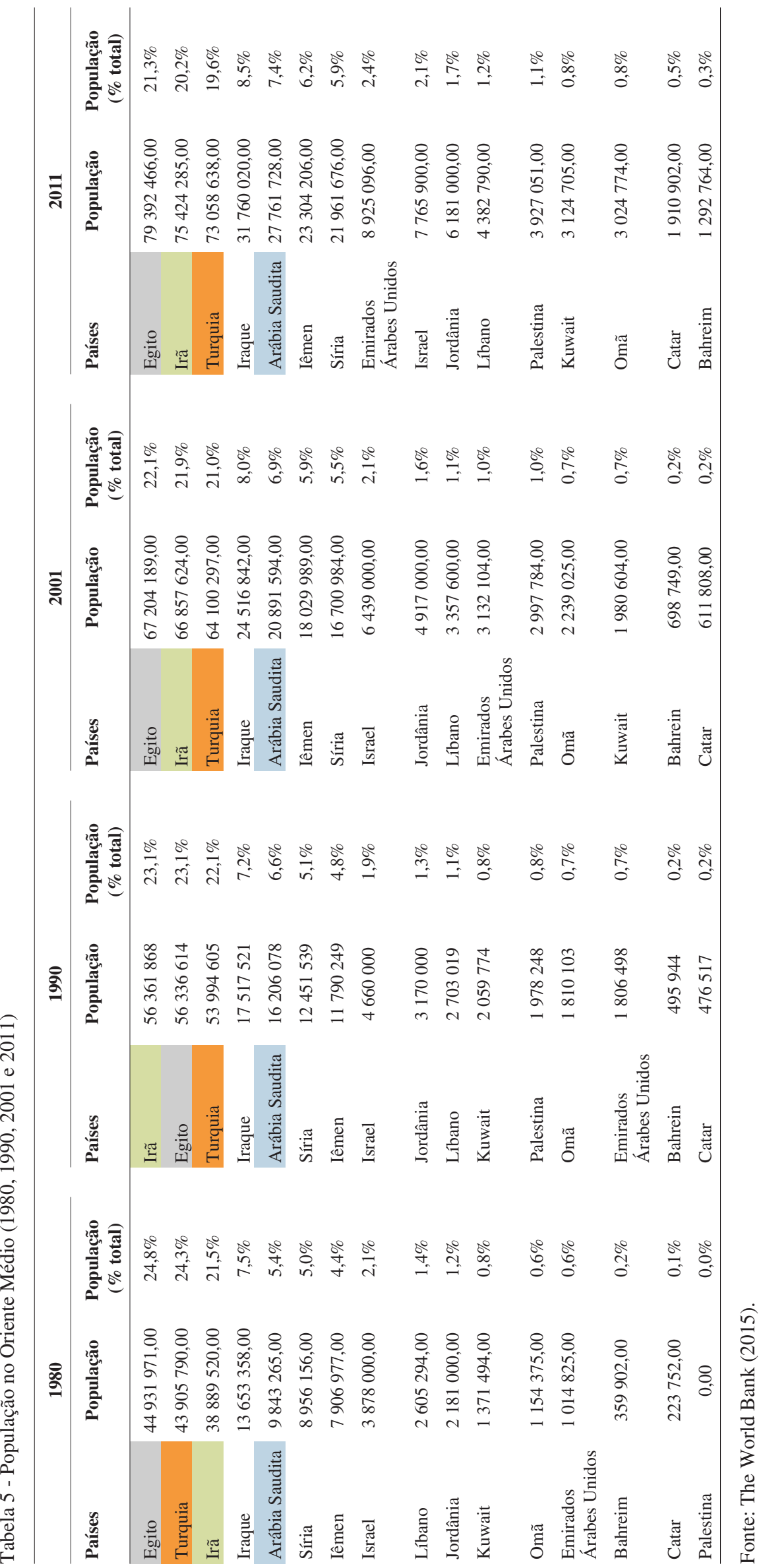




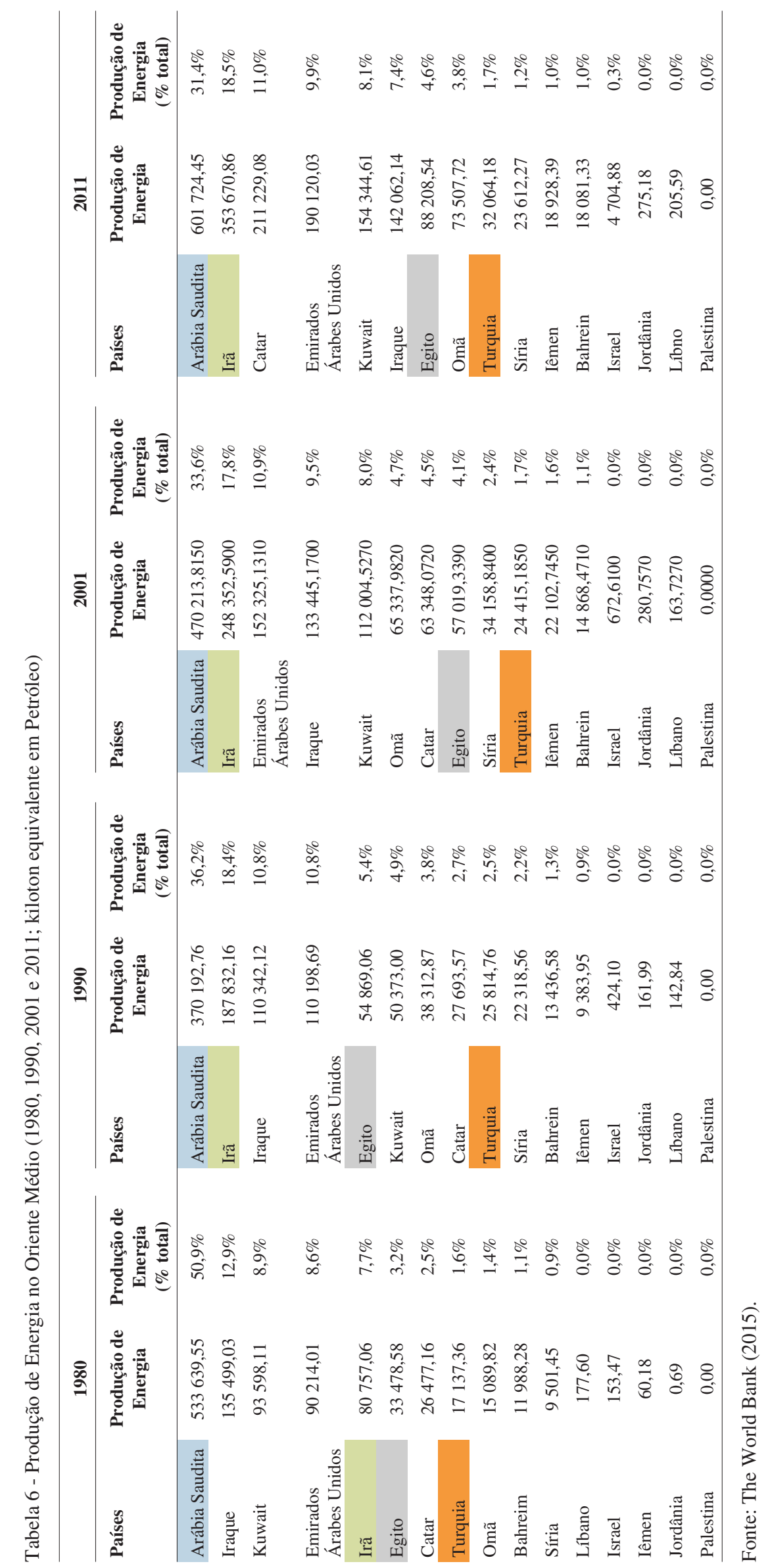


5 Para o tratamento dos dados e aplicação do método multivariado foi utilizado o software SPSS de suas fartas reservas de petróleo. Esses países são importantes financiadores e investidores regionais, e em alguns momentos participam também de ações políticas relevantes.

Já na Tabela 7 é possível perceber como o fator tamanho populacional e produção industrial estão intimamente ligadas ao consumo de energia. Em todos os anos analisados os quatro principais países figuram nas primeiras posições, o que revela a necessidade de consumo de grandes populações e a forte atividade industrial. É importante destacar que Turquia e Irã são tidos como países que poderiam fazer parte de uma possível expansão do bloco BRICs, das economias de países emergentes. Isso demonstra o nível da atividade industrial desses países.

Para facilitar o entendimento da hierarquia de poder material (poder real e potencial) da região, utilizou-se da análise multivariada (ACP). Ao se utilizar esse método, buscou-se entender um fenômeno através das inúmeras variáveis que o influencia e não apenas através de uma relação isolada entre elas. A análise multivariada "[...] refere-se a todos os métodos estatísticos que simultaneamente analisam múltiplas medidas sobre cada indivíduo ou objeto sob investigação. Qualquer análise simultânea de mais de duas variáveis pode ser considerada análise multivariada" (Hair 2005, p. 26).

O método de análise multivariada está sendo frequentemente utilizado pelos pesquisadores por apresentar uma abordagem mais global de um determinado fenômeno ou acontecimento, seja por meio de uma análise única sobre fenômenos que antes eram investigados através de múltiplas análises da técnica univariada, seja, então, como técnicas específicas para trabalhar com questões multivariadas, a exemplo da análise fatorial e da análise discriminante (idem).

Outro aspecto importante desse método é a possibilidade de utilização de softwares específicos ${ }^{5}$ para o tratamento e análise dos dados, o que facilita o trabalho do pesquisador, anteriormente limitado pelo número de cálculos necessários para a análise dos dados. Entre os inúmeros métodos de análise multivariada, destaca-se para, este artigo, a Análise de Componentes Principais (ACP), utilizado para se verificar a maneira pela qual as amostras se relacionam, isto é, as semelhanças dessas de acordo com as variáveis utilizadas no trabalho. Esse tipo de análise baseia-se na redução do número de variáveis a fim de fornecer uma visão estatisticamente privilegiada do conjunto de dados (Neto 2004). A análise de componentes principais consiste em reescrever as variáveis originais em novas variáveis denominadas componentes principais.

O objetivo é encontrar um meio de condensar a informação contida em um número de variáveis originais em um conjunto menor de variáveis estatísticas (fatores) com uma perda mínima de informação. Pelo fato de fornecer uma estimativa empírica da "estrutura" das variáveis consideradas, a análise fatorial se torna uma base objetiva para criar escalas múltiplas (Hair 2005, p. 32).

Dessa forma, ao final das análises individualizadas das tabelas com as sete variáveis de poder, aplicaremos a Análise de Componentes Principais para reduzi-las a apenas uma componente, permitindo observar, ao decorrer das décadas, a hierarquia de poder (no âmbito material) entre os principais atores da região.

Um passo importante foi avaliar o grau de relacionamento existente entre os dados destas sete variáveis, para que essa nova componente pudesse de fato representar a realidade traduzida em uma única componente principal. Aqui, após inserir os dados no software, foi encontrado um alto grau de variância na Componente 1, isso é, $67,84 \%$ do comportamento dos dados das sete variáveis podem ser explicados pela primeira componente principal encontrada. Esse alto grau de correlação múltipla permite dizer que essas variáveis são bastante 


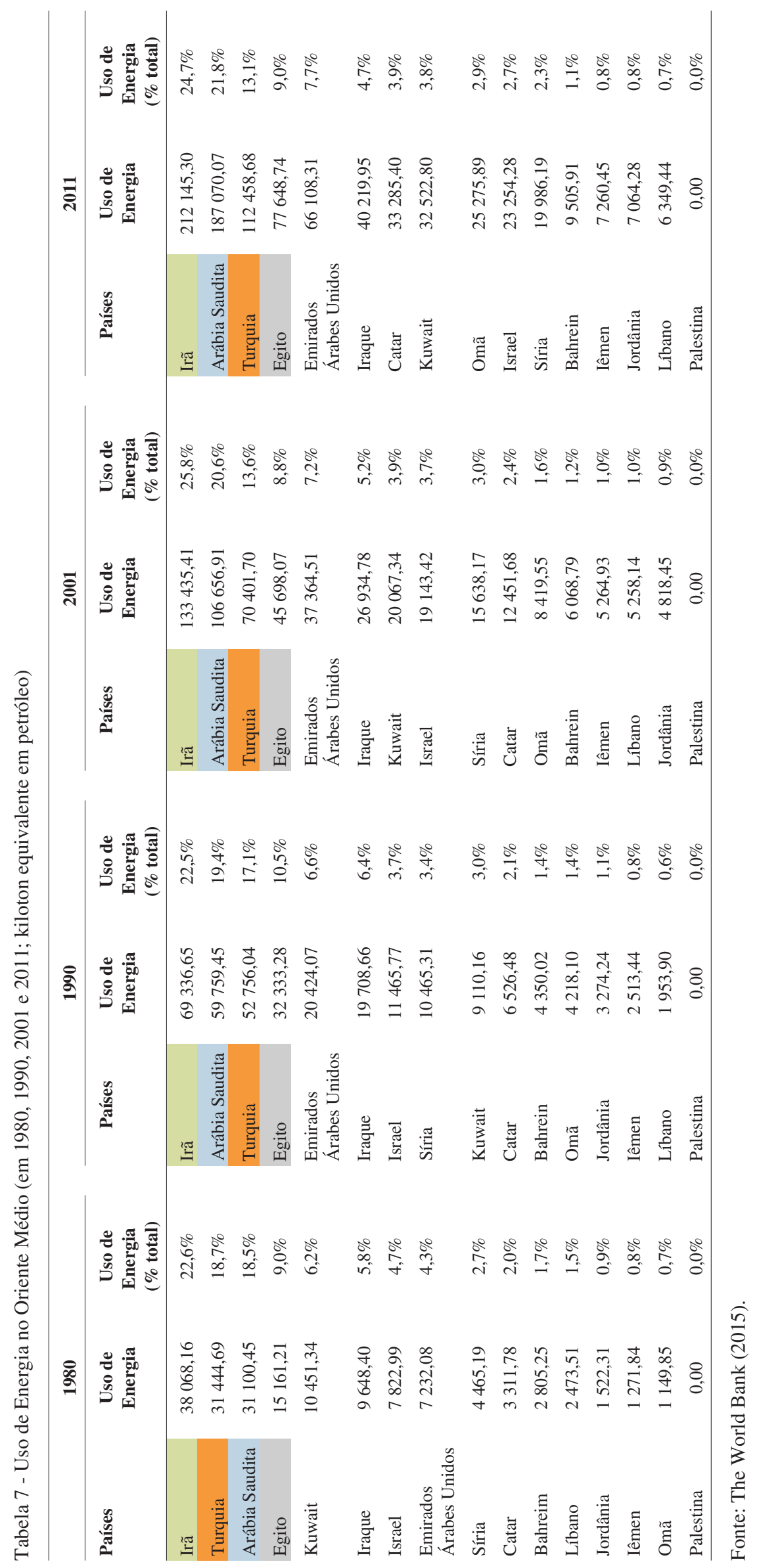


representativas para compreender o que nós definimos como poder material (junção de poder real e potencial). Ao mesmo tempo, foi feito um ranking dos resultados obtidos e transformamos os resultados encontrados em uma escala de 0 a 1, para facilitar as análises, sendo que 1 representa o valor máximo de poder e 0 o valor mínimo.

Os resultados encontrados após o tratamento estatístico (ACP) corrobora a visão histórica apresentada pela bibliografia consultada e reafirma a importância de forças tradicionais na região. Sem dúvida, o papel da produção e uso do petróleo e do PIB interferiu fortemente no resultado, o que explica a ascensão dos Emirados Árabes Unidos nos últimos anos, e a posição israelense abaixo do esperado. O que explica o resultado israelense é o apoio externo que recebe para manter sua preponderância militar. O tamanho de seu território, sua economia, bem como suas fontes de energia diminuem seu poder material, porém, os acordos de cooperação militar com a maior potência mundial e o apoio político irrestrito desse país à política externa israelense confere uma capacidade de atuação intensa, principalmente na dimensão estratégico-militar.

A Tabela 8 demonstra que nos anos de 1980, 1990, 2001 e 2011, as principais forças regionais no Oriente Médio eram formadas pela Arábia Saudita, Irã, Turquia e Egito, sendo a Arábia Saudita o ator mais poderoso na região. Outro dado relevante é com relação à distância de poder existente entre eles. Na década de 1980, a distância que separavam os quatro atores principais era razoavelmente grande (em função da importância do petróleo), tendência que foi diminuindo com o tempo. É importante chamar atenção para o fato de que as posições na hierarquia de poder gerada pela ACP se mantiveram as mesmas nos quatro anos analisados. Isso demonstra a força inercial desses atores durante um longo período de tempo.

A capacidade de sintetizar as sete variáveis que representariam o poder material (poder real e poder potencial), por meio da ACP, ajuda a perceber de maneira mais clara a distribuição do poder estatal na região e como esses quatro atores frequentemente disputaram a liderança no Oriente Médio, cada um a seu tempo.

Tabela 8 - Análise de Componentes Principais no Oriente Médio (1980, 1990, 2001 e 2011)

\begin{tabular}{|c|c|c|c|c|c|c|c|}
\hline Nome do País & 1980 & Nome do País & 1990 & Nome do País & 2001 & Nome do País & 2011 \\
\hline Arábia Saudita & 1 & Arábia Saudita & 1 & Arábia Saudita & 1 & Arábia Saudita & 1 \\
\hline Irã & 0,6944 & Irã & 0,8679 & Irã & 0,8544 & Irã & 0,8422 \\
\hline Turquia & 0,5524 & Turquia & 0,7149 & Turquia & 0,6797 & Turquia & 0,6464 \\
\hline Egito & 0,3991 & Egito & 0,5024 & Egito & 0,5981 & Egito & 0,5074 \\
\hline Iraque & 0,3366 & Iraque & 0,3219 & Iraque & 0,2789 & Iraque & 0,3424 \\
\hline Israel & 0,2024 & Israel & 0,2064 & Israel & 0,2735 & EAU & 0,3026 \\
\hline Kuwait & 0,157 & EAU & 0,2014 & EAU & 0,2606 & Israel & 0,1747 \\
\hline EAU & 0,1457 & Kuwait & 0,1749 & Síria & 0,1859 & Catar & 0,142 \\
\hline Síria & 0,1318 & Síria & 0,1487 & Kuwait & 0,1339 & Kuwait & 0,1366 \\
\hline Iêmen & 0,0808 & Iêmen & 0,1144 & Iêmen & 0,131 & Iêmen & 0,1181 \\
\hline Omã & 0,0743 & Omã & 0,1045 & Omã & 0,1136 & Omã & 0,1078 \\
\hline Jordânia & 0,0523 & Catar & 0,0447 & Catar & 0,056 & Síria & 0,1018 \\
\hline Catar & 0,0393 & Jordânia & 0,0387 & Jordânia & 0,049 & Jordânia & 0,0385 \\
\hline Bahreim & 0,0261 & Bahreim & 0,0259 & Líbano & 0,0464 & Líbano & 0,0271 \\
\hline Líbano & 0,0215 & Líbano & 0,0174 & Bahreim & 0,0217 & Bahreim & 0,0157 \\
\hline Palestina & 0 & Palestina & 0 & Palestina & 0 & Palestina & 0 \\
\hline
\end{tabular}

Fonte: Os autores, a partir de The World Bank (2015). 


\section{V.3. Ativismo regional, reconhecimento regional e papel estabilizador}

Essas três características, também centrais para definir uma potência regional, é um dos principais dilemas a ser avaliado no caso em tela. $\mathrm{O}$ ativismo regional, bem como o reconhecimento de ser uma liderança por parte dos demais Estados, e o papel de agente estabilizador, não pode ser creditado a somente um ator regional, em função da acirrada disputa política entre Arábia Saudita e Irã. Na história contemporânea da região, o ativismo egípcio perdurou desde a era Nasser até sua aproximação com Israel ao final da década de 1970, e sua liderança regional foi contestada em vários momentos por Iraque, Síria e ao final do processo que normaliza as relações entre o Egito e Israel, pela própria Arábia Saudita. Após os atentados de 11 de setembro, o Egito manteve uma posição de mediação entre o mundo árabe muçulmano e seus aliados ocidentais, mas não praticou uma política ativa na área.

A Turquia, potência colonial que organizou o sistema árabe-muçulmano durante séculos e que chegou ao fim após a I Guerra Mundial, também experimentou um recuo vigoroso de sua presença regional com a proclamação da República Turca em 1923. Esse afastamento da política regional se manteve até o início do século XXI. Com a ascensão de Erdogan ao poder em 2002, a ação política na região se tornou mais evidente e o modelo da República Turca começou a ser visto como uma saída para os dilemas dos governos na região. A Turquia não disputa a liderança política da área, mas inicia um processo mais forte de interlocução com os Estados pertencente a esse subsistema regional.

Por outro lado, o Irã, que já foi um importante aliado estadunidense durante o governo do Xá Reza Pahleve, se transformou em um dos maiores desafios para o ordenamento regional, com o início da revolução islâmica. A partir da década de 1980, os interesses do Irã estavam voltados para a expansão da Revolução Islâmica e isso confrontava diretamente com os projetos das monarquias do Golfo Pérsico, bem como das Repúblicas comandadas por maiorias sunitas. É interessante perceber que o principal antagonismo regional se dá entre a principal força do xiismo, representado pelo Irã, e o berço do islamismo, liderado pela dinastia sunita Wahabita da família real dos Saud, na Arábia Saudita.

Já a Arábia Saudita, que surge como principal força regional, utilizou ao longo de sua história recente de seus recursos energéticos para patrocinar as mudanças políticas. O Reino da Arábia Saudita foi fundamental na Guerra do Yon Kippur, ao financiar a aliança trilateral, e ao mesmo tempo, teve papel central ao permitir a entrada das tropas estadunidenses em seu território para combater as forças iraquianas após a invasão deste país ao Kuwait. A disputa da Arábia Saudita se dá principalmente contra movimentos extremamente liberais ou contra as forças xiitas que buscam avançar sobre a região, sendo o Irã um adversário antigo que põe a prova a sua capacidade de ordenar o subsistema regional.

Dessa forma, podemos concluir que não é possível apontar uma única potência regional, devido à divisão existente principalmente entre as forças políticas locais, regionais e mundiais que apoiam sauditas ou iranianos. O reconhecimento do papel desses atores se dá por seus respectivos aliados regionais, não existindo um consenso sobre uma única força que represente a região ou que possa gerar estabilidade na mesma. O papel da Arábia Saudita e do Irã nesse contexto é fundamental, pois representam bem as disputas regionais, que são anteriores aos atentados de 11 de setembro, e continuaram após os mesmos. Israel também têm responsabilidades para com o ordenamento regional, sendo ele um elemento de desestabilização, responsável muitas vezes 
${ }^{6}$ Grupo formado por Brasil, Rússia, Índia, China e África do Sul, que são reconhecidos como economias emergentes no cenário internacional e que desenvolvem relações de cooperação política e econômica.

${ }^{7}$ Para Silva (2013), esse conceito foi elaborado pelo banco de investimento Goldman Sachs para classificar países com potencialidade de se transformarem em economias emergentes. Também conhecidos como pequenos BRICs. por reforçar o sentimento de solidariedade entre árabes, persas e turcos a favor da causa palestina.

O poder ideacional tem ganhado força como elemento de poder nas Relações Internacionais. As práticas de um determinado Estado, bem como sua capacidade de participar em organizações internacionais de relevância para a governança global, representam algumas características desse poder difuso. Dessa forma, podemos dizer que a força do poder ideacional está nas práticas estabelecidas pelo Estado e sua participação ativa em organismos internacionais que orientam a vida política da ordem internacional.

Esse ativismo político permitirá a criação de uma imagem compartilhada de força ou fraqueza, justiça ou inequidade, dependendo das práticas destes atores internacionais. A imagem gerada a partir dessas ações poderá criar identificação com outros atores internacionais, o que viabilizaria um sentimento de solidariedade em questões de política externa ou alianças políticas por afinidade e identificação de objetivos comuns.

Do ponto de vista do poder ideacional em sua dimensão econômica, Turquia e Irã surgem como fortes candidatos a futuros membros dos BRICs ${ }^{6}$, em função do avanço de suas economias e da relevância regional de seus países. Além disso, de acordo com Silva (2013), Egito, Irã e Turquia também aparecem como pertencentes ao grupo "Next Eleven" ", conjunto de países que possuem grande possibilidade de se tornarem economias emergentes ao lado dos BRICs nos próximos anos, em função de suas características econômicas. Além disso, Arábia Saudita e Turquia fazem parte do G20, grupo de países formados pelas 20 maiores economias do globo, que visa facilitar o intercâmbio comercial e a estabilidade da economia política internacional. As economias desses países representam em torno de $90 \%$ do PIB mundial.

Outra organização importante é a OPEP (Organização dos Países Exportadores de Petróleo), em função de seu caráter estratégico na distribuição e controle da oferta de petróleo para o Sistema Internacional. Dentre seus membros destacam-se a Arábia Saudita e Irã. A OPEP é responsável por $81 \%$ de todas as reservas de petróleo do mundo, sendo que a Arábia Saudita possui a segunda maior reserva e o Irã a terceira, entre seus membros (OPEC 2012).

Do ponto de vista do poder ideacional político, a participação nas Nações Unidas é um indicador importante da relevância e da tradição destes países na governança da agenda de segurança do Sistema Internacional. Desde a Fundação das Nações Unidas, Arábia Saudita, Egito, Irã e Turquia, foram signatários fundacionais da organização, assim como Líbano e Síria. Como membros temporários do Conselho de Segurança das Nações Unidas, Egito e Turquia foram os países que mais participaram na região, com quatro gestões cada um. O Irã participou por uma vez e a Arábia Saudita foi eleita para o mandato de 2014 a 2015, mas rejeitou o assento em protesto à inação do Conselho de Segurança acerca do Irã e do governo sírio em virtude da guerra civil na Síria. Israel foi o único país que nunca participou como membro temporário do Conselho de Segurança na região. Vale lembrar também que Turquia é um membro antigo da Organização do Tratado do Atlântico Norte (OTAN), o que confere a ela papel de destaque na condução dos problemas da segurança internacional.

Dessa forma, fica evidente a existência de certo ativismo político de Egito, Turquia, Irã e Arábia Saudita no contexto do Oriente Médio. Todos esses países participam, em maior ou menor grau, de organismos importantes para a governança global, seja estimulando a economia política internacional, seja envol- 
vendo-se em questões centrais da segurança global. Sem dúvida, a baixa participação da Arábia Saudita e do Irã, e a não participação de Israel no Conselho de Segurança é um indicador importante, pois reflete as complexas disputas travadas por esses atores na região, o que diminui a possibilidade de participação desses países no Conselho.

\section{Conclusões}

Após os atentados de 11 de setembro de 2001, muito se falou de transformações importantes no ordenamento mundial e regional do Oriente Médio, em virtude da luta empreendida pelos Estados Unidos contra o terrorismo transnacional. O que se pode concluir após essa breve discussão é que, do ponto de vista do poder material, os atentados de 11 de setembro não alteraram as principais forças estatais que tradicionalmente estimulavam a região. Arábia Saudita, Irã, Turquia e Egito continuam tendo papel de relevância na dinâmica regional.

Também pode-se destacar duas potências regionais, Arábia Saudita e Irã, acompanhadas por duas potências emergentes, Turquia e Egito. Isso demonstra a dificuldade em estabelecer uma única potência regional, pois, como afirma o próprio Nolte (2010), o que diferencia uma potência emergente de uma potência regional é o reconhecimento local e internacional de sua liderança e seu caráter estabilizador na região, algo polarizado e disputado por Arábia Saudita e Irã. Cada um deles possui seus aliados regionais, e a polaridade da disputa é evidente em conflitos como o da Síria, do Iraque e do Líbano. Outro aspecto importante, respondido por esta pesquisa, é o papel central das potências regionais, sendo que os desígnios das políticas locais dos Estados sofrem impacto direto dos estímulos gerados por estes dois atores.

Porém, uma realidade se transformou claramente e tem gerado perturbações intensas no ordenamento regional, dizendo respeito ao âmbito transnacional. Desde os atentados de 11 de setembro de 2001, a luta contra o terrorismo gerou uma ressignificação no entendimento das relações entre estados e forças transnacionais. Esse aspecto está diretamente ligado ao domínio ideacional, isto é, a compreensão que temos acerca do terrorismo, e como combatê-lo, alterou significativamente a política dos Estados. O crescimento e fortalecimento de grupos terroristas ligados à $\mathrm{Al}$ Qaeda, e de outras organizações que visam transformar a realidade política do Oriente Médio por meio do uso da violência, têm gerado uma significativa transformação da geografia da região. O avanço do grupo extremista islâmico "Califado do Estado Islâmico do Iraque e Levante" sobre a Síria, Iraque e Líbano tem gerado muitas preocupações tanto em Estados xiitas como nas monarquias sunitas da região. A incapacidade de controlar o avanço dessas forças demonstram o imenso desafio que o terrorismo internacional e a ideologia do islã radicalizado impõe sobre o mundo após o 11 de Setembro.

Se por um lado as forças materiais continuam as mesmas, por outro as forças ideacionais têm gerado transformações profundas. A política externa de vários países, bem como as táticas empregadas para o controle destes movimentos, estão sendo ditadas pelos desdobramentos ocorridos após os erros e acertos do 11 de Setembro. É necessário observar que entre esses dois domínios, material e ideacional, o maior impacto dos atentados são sentidos no mundo das ideias, mas seus desdobramentos observados no redesenho das fronteiras da região.

Danny Zahreddine (danny @ pucminas.br) é Doutor em Geografia pela Pontifícia Universidade Católica de Minas Gerais (PUC Minas) e Professor Adjunto IV do Departamento de Relações Internacionais da mesma universidade. 
Rodrigo Corrêa Teixeira (rteixeira@ pucminas.br) é Mestre em História pela Universidade Federal de Minas Gerais (UFMG) e Professor Assistente IV do Departamento de Relações Internacionais da Pontifícia Universidade Católica de Minas Gerais (PUC Minas).

\title{
Referências
}

Barnett, M.; Duvall, R. 2005. Power in International Politics. International Organization, 59(1), pp. 39-75.

Bull, H. 2002. The Anarchical Society. $3^{\mathrm{a}}$ ed. Basingstoke: Palgrave.

Buzan, B. 2003. Regions and Powers: The structure of international security Cambridge (UK): Cambridge University.

Carr, E.H. 2001. Vinte anos de crise, 1919-1939: uma introdução ao estudo das Relações Internacionais. Brasília: Editora da UnB.

Cleveland, W.L.; Bunton, M. 2009. A History of the Modern Middle East. Philadelphia: West View Press.

Fawcett, L. 2005. International Relations of the Middle East. Oxford: Oxford University Press.

Hair, J.F. 2005. Análise multivariada de dados. Porto Alegre: Bookman.

Huelsz, C. 2009. Middle Power Theories and Emerging Powers in International Political Economy: A case study of Brazil. Manchester. Tese (Doutorado em Relações Internacionais). University of Manchester.

Jordaan, E. 2010. The Concept of a Middle Power in International Relations: Distinguishing between emerging and traditional middle powers. Politikon, 30(1), pp. 165-181.

Mearsheimer, J.J. 2001. The Tragedy of Great Power Politics. New York: W.W. Norton \& Company.

Neto, J.M.M. 2004. Estatística multivariada: uma visão didática-metodológica. Disponível em: http://criticanarede.com/cien_estatistica.html. Acesso em: 8 fev 2015.

Nolte, D. 2010. How to Compare Regional Powers: Analytical. Review of International Studies, 36, pp. 881-901.

Seddon, D. 2004. A Political and Economic Dictionary of the Middle East. New York: Taylor \& Francis Group.

Silva, A.L.R. 2013. Os países emergentes na política internacional: o grupo Next Eleven (N-11) e as convergências com a política externa brasileira. Estudos Internacionais, 1(2), pp. 205-222.

Taylor, A.R. 1982. The Arab Balance of Power. Syracuse: Syracuse University Press.

Waltz, K.N. 2002. Teoria das relações internacionais. Lisboa: Gradiva.

Zahreddine, D. 2003. A imprevisibilidade do conflito anglo-americano no Iraque. Conjuntura Internacional, 1, pp. 1-3.

Zahreddine, D.; Lasmar, J.M.; Teixeira, R.C. 2011. O Oriente Médio. Curitiba: Editora Juruá.

\section{Outras fontes}

OPEC. 2013. OPEC Annual Statistical Bulletin. Disponível em: http://www.opec.org/opec_web/en/data_graphs/330.htm. Acesso em: 29. jul. 2014.

Sipri. 2014. Stockholm International Peace Research Institute database. Disponível em: http://www.sipri.org/research/armaments/milex/milex_database/milex_database. Acesso em: 5 fev 2015.

The World Bank. 2015. World Data Bank. World Development Indicators. Washington, D.C.: World Bank.

\begin{abstract}
This article will analyse the Middle East regional order fifteen years after the attacks of September eleven 2001, showing the relevance of regional forces for the balance of power in the region. The question to be answered in this article is if the attacks of September eleven have changed significantly the regional order. The goal of the research is to assess the role of regional forces to power relations in the Middle East, and their transformations after the attacks. To do so, will be presented the concepts of power, order, and regional power, as well as a brief description of the changes that have occurred in international relations in the Middle East, since the local independence until the period after September eleven, 2001. To categorize States as traditional middle power, emerging power or regional power, will be used the theoretical perspective created by Nolte (2006), Jordaan (2003) and Huelsz (2009). To evaluate the distribution of power between the main State actors, as well as their hierarchy of power, we will use the concepts of real power, potential power and ideational power, and apply some statistical techniques such as principal components analysis (PCA), to analyze the periods of 1980, 1990, 2001 (year of the attacks), and 2011 (latest data sources consulted). The results demonstrate that the main regional forces that have historically acted in the region are still present, and that the actual regional order is similar to the early 1990 's, with the main transformations have taken place in the ideational domain, due to the increased action of transnational forces.
\end{abstract}

KEYWORDS: Middle East; regional order; power; regional power; September 112001.

License information: This is an open-access article distributed under the terms of the Creative Commons Attribution License, which permits unrestricted use, distribution, and reproduction in any medium, provided the original work is properly cited. 